\title{
Benefits and the hidden face of the maker movement: Thoughts on its appropriation in African context
}

\author{
Os benefícios e a face oculta do movimento maker: Reflexões sobre \\ sua apropriação no contexto africano
}

Thomas Hervé Mboa Nkoudou*

\section{RESUMO}

O objetivo deste artigo é explorar os benefícios do e as críticas ao movimento maker, na perspectiva de sua adoção no contexto africano. O método usado foi a revisão da literatura, que revela que o movimento maker está incorporado à ética maker, ao DIY e a ideologias de software livre. Essas ideologias trazem valores como abertura, compartilhamento, inclusão, democratização e colaboração, que são o âmago dos benefícios sociais, políticos e econômicos do movimento maker. Mesmo que esses benefícios estejam infiltrados pelo capitalismo, a busca da justiça cognitiva e a filosofia do Commons parecem ser as ferramentas epistemológicas certas para a adoção do movimento maker na África.

Palavras-chave: Movimento Maker; Justiça Cognitiva; Commons; Hackerspace; DIY.

\begin{abstract}
The aim of this paper is to explore benefits and critics of the maker movement, in the perspective of its adoption in African context. The method used is a literature review, which reveals that the maker movement is embodied in hacker ethics, DIY and free software ideologies. These ideologies bring values like openness, sharing, inclusion, democratization, and collaboration which are the core of the social, economic and political benefits of the maker movement. Even if these benefits are infiltrated by capitalism, the quest of cognitive justice and the Commons philosophy, seems to be the right epistemological tools for the adoption of the maker movement in Africa.
\end{abstract}

Keywords: Maker Movement; Cognitive Justice; Commons; Hackerspace; DIY.

\section{INTRODUCTION}

The great technological advances made in the digital field have societal impacts that cannot be refuted or even less concealed. With the Internet, information flows instantaneously around the world, offering the opportunity to exchange, share, and contribute to the enrichment of knowledge. This web 2.0 trend facilitates exploitation of information for individual or community purposes, in spaces open to citizens, where common reflection, creation, and innovation occur. The collaborative dimension and the presence of machine tools in these spaces give citizens the

\footnotetext{
* BSc, M.Ed. M.A. Université Laval/Department of Information and communication. Université Laval, Québec, Canada, G1V oA6 1055, Avenue du Séminaire Pavillon Louis-Jacques-Casault. Telefone: +1418 656-2131, poste 4235. E-mail: thomas-herve.mboa-nwoudou.1@ulaval.ca or thomasmboa@gmail.com.
} 
opportunity to create, tinker, design and manufacture objects according to their needs. This new revolution, known as the maker movement, has led to an increase in the number of these spaces in recent years. In this paper, I used a literature review as method, to better understand this phenomenon. The first section of the article presents the ideological foundations of the maker movement and its related spaces. The first part of the second section addresses the advantages that explain the maker's rush. The second part is a critique of the movement, since its hidden face is unveiled. The last section presents my thoughts on the effective appropriation of the maker movement in the African context.

\section{THE MAKER MOVEMENT AND RELATED SPACES}

\section{Ideological Foundations}

According to Lallement (2015) the hacker ethic, DIY (Do-it-Yourself) and the idea behind the free software movement are core ideologies of the maker movement.

\section{Hacker Ethic}

Initially, the term hacker was applied to members of precocious college students' groups, because they were among the first to make a hobby of experimenting with computer programming in 1950 (Bowen 2017). Unfortunately, the term hacker has gained a negative connotation as "a person who illegally breaks into a computer system and steals valuable information, codes or destroys online projects" (Stercken 2015). Today, this concept is used positively and it is not limited to computer sciences, because a hacker is an expert or an enthusiast of any kind who develops a passionate relationship with the work (Himanen 2001, 10); and hacking is the act of adapting an existing object, code, or activity to fit one's needs (Barniskis 2014). Due to the enlargement of the concept, Bowen (2017) has identified four notions actually associated with the term. Hacking as collaboration through shared access, where the vision is an ethical commitment of sharing authority, expertise, and information. Hacking as problem-solving: this form of hack-is related to activities aimed at altering and/or repurposing processes or products in order to make an intended improvement. Subversion invokes hacking as a form of progressive boundarycrossing in order to challenge the status quo. Finally, as exploration hacking is used to describe activity done purely for the sake of doing it, without concerns about the quality, the results, or the risks that might present themselves along the way.

As a very important part of the maker movement, hacking is embodied in the following "Hacker Ethic" principles: "strong belief in access to technology and information, which included a desire for hands-on learning [...] mistrust of authority [...] belief in meritocracy rather than evaluating hackers by their degrees, age, race, or position; and belief that computers could improve life for the better" (Bowen 2017).

\section{Do-It-Yourself}

According to Anderson and Le Séac'h (2012), DIY combines digital autofabrication, online collaboration and the use of common file formats. The work is for yourself and 
it is characterized by enthusiasm for hacking, handicrafts, and tinkering; without any objectives or deadline obligations (Lallement 2015).

\section{Free Software}

This is the transposition of the four freedoms granted to users of free software. That is: execute a program as desired and for any use; have access to source code; study the functioning of the program and modify it as we want; finally, be able to share copies of the program.

\section{Related Spaces}

The reification of the maker movement occurs in particular collaborative, creative, or innovative places. Broadly speaking, these places are physical environments that promote community, learning, and making; where people with common interests, often in computers, technology, science, digital or electronic art (but also in many other realms) can meet, socialize and/or collaborate. For Stercken (2015), these spaces are "enabling spaces' that enhance users' social capabilities, their intellectual capabilities and their psychological capabilities, in addition to benefitting their economic capital". While they exist in different forms, they have common characteristics which provide opportunities to engage with people, ideas, and technologies; experience participatory culture and to acquire the literacy and skills needed (Barniskis 2014; Stercken 2015).

\section{Common characteristics}

Stercken (2015) has identified five common dimensions to these spaces: architectural, technological, virtual, social and cultural \& organizational.

The architectural dimension refers to the structure and the design of the physical environment. According to Stercken (2015), "the 'architectural space' constitutes the physical environment which people can visit, experience and get involved with people, ideas and technologies inside of". The technological dimension refers to emerging technologies, materials and tools such as: computers, the internet, simulation and prototyping technologies, 3D printers, CNC machines, routers, precision laser cutters... Even if a typical space is equipped with computing tools allowing experimenting with the physical/digital boundary, they also offer more traditional hand and power tools, sewing machines, or craft supplies (Brady et al. 2014; Lindtner 2014; Barniskis 2014).

The virtual dimension is related to online platforms, websites and blogs in which users can virtually interact and access additional knowledge sources (Stercken (2015). The social dimension refers to communities. Finally, the cultural and organizational dimension is based on six principles: collaboration, openness, community, accessibility, sustainability and promotion of a hacking/making/do-it-yourself (DIY) culture.

Collaboration or sharing refers to the provision of a high-contact environment, where space and tools are shared, where doors are typically not closed and users can approach each other when they need help or feedback for something. [...] 'Openness' refers to the freedom/flexibility innovation spaces offer to their users, in the 
sense of allowing them to come whenever they want to and pay by usage. Also, the principle of openness relates to the idea that users are free to co-create the (architectural) space according to the community's shared or users' individual needs [...] 'Community', and thus the emphasis on the people/users, their interactions and relations (social space), rather than on the technologies provided, stands at the centre of all innovation spaces. [...] 'Accessibility' generally relates to the idea that innovation spaces should be accessible to anyone who wants to be part of the space and feels at ease with the values and principles practiced there. [...] 'Sustainability' refers to the idea that the practice of sharing space, tools, and resources in itself constitutes a more sustainable work model than if every user had his/her own office or workshop (Stercken 2015, 10).

\section{Types of Spaces}

The close relation between the maker movement and the rapid evolution of technology has led to the proliferation of innovative, collaborative and creative spaces. They can take different forms, like makerspaces, hackerspaces, labs, coworking spaces, hubs, techshops...

\section{- Hackerspaces}

On the website www.hackerspaces.org, hackerspaces are broadly defined as community-operated physical places, where people can meet and work on their projects. Some authors put technology at the core of hackerspaces and define them as "community spaces created by people committed to new approaches towards technology use and design, based on the open sharing of software code and hardware designs" (Lindtner 2014). It is true that technology is very important in these spaces, but they cannot be limited to it. Thus, I can define hackerspaces as places of meeting and collective experimentation that bring together people sharing a common interest in a particular topic, which can be: arts, science, technology, agriculture, computer science ... These places are informally organized and function autonomously vis-à-vis institutions.

According to Lallement (2015), the Chaos Computer Club (CCC) is the first hackerspace, born on September 12, 1981 in Berlin, as the result of a gathering by young people passionate for computer science. Since 2009, another kind of hackerspace has emerged: the so-called biohackerspaces. These are rudimentary biology laboratories, located outside the conventional spaces of universities and research centres. These forms of laboratories pursue the ideals of hacking and DIY, but applied to biology (Meyer 2012).

\section{- Makerspace}

Brady et al. (2014) define makerspaces as places where people come together to create and share resources, knowledge, and stuff. They allow collaboration and teamwork, in such a way that makers with complementary skill sets and viewpoints can work together and find solutions that would not have occurred individually.

- Lab

Stercken (2015), talking about an interview with Christine Prefontaine specifies that: 
the term 'lab' stands for laboratory and refers to an environment where ideas, products or services can be tested in a protected manner. While labs may in a sense be protected from the outside, inside there is usually a culture of 'open innovation', where ideas and knowledge are shared openly among its visitors who may previously be unfamiliar with each other, creating opportunities for feedback and collaboration. Stercken (2015)

\section{- FabLabs}

One of the more well-known labs is FabLab, for Fabrication Laboratory. They are physical places or workshops of "rapid prototyping of physical objects," "intelligent or not ", where machines, tools and computers are shared in order to carry out projects, individually or collectively (Buclet 2015; Lallement 2015; Bouvier-Patron 2015; Eychenne 2012; Bosqué 2015b). The first Fablab was started at the end of the 1990s, in the Center for Bits \& Atoms of the Massachusetts Institute of Technologies (MIT). According to Lallement (2015) and Bosqué (Bosqué 2015a), they are designed to facilitate access to technology, to allow any community to become more creative. Its objective is the empowerment of populations, with the aim of contributing to the democratization of technological design and thus enable each of us to become an inventor through mastery of personal digital manufacturing. Although the ideological foundations of FabLabs are the same as those of hacker/makerspaces, they are different. This is because FabLabs are formally connected to the MIT network and require adhesion to the usage of the specific set of technology promoted by the MIT/Fab Lab movement, whereas the hacker/makerspaces are autonomous (Stercken 2015).

- Living Lab

It is a physical or virtual space where projects are tested and collaborative researchdevelopment is conducted. It brings together private, public, business, associations and individuals (Nedjar-Guerre and Gagnebien 2015). Like FabLabs, livinglabs were created at MIT. To be recognized as Livinglabs, it is necessary to first obtain a European Network of Living Labs (ENoLL) certification (Capdevila 2015).

- Coworking space

Coworking spaces are shared workplaces for independent professionals, start-up entrepreneurs or anyone with workplace flexibility from a wide variety of professional backgrounds. They prefer to work side-by-side by sharing resources and being willing to share their knowledge with the rest of the local community (Capdevila 2015; Stercken 2015). According to Kojo and Nenonen (2014), the coworking space is the actual stage of the earliest telecentres and services offered; and it is related to new ways of working: collaboration, openness, community, accessibility, attractiveness, work-life balance, economic efficiency, sustainability and regional development. Even if these places are economy-oriented, the promotion of these values is what distinguishes them from other workplace concepts, such as office rentals and business incubators, for which community-building is not essential (Kojo and Nenonen 2014; Stercken 2015). Finally, coworking spaces can be defined as:

workplaces utilized by different sorts of knowledge professionals, mostly freelancers, working in various degrees of specialization in the vast domain of the knowledge industry. Practically conceived as office-renting facilities where workers hire a desk and a Wi-Fi connection these are, more importantly, places where independent professionals live their daily routines side-by-side with 
professional peers, largely working in the same sector - a circumstance which has huge implications on the nature of their job, the relevance of social relations across their own professional networks and - ultimately - their existence as productive workers in the knowledge economy. (Gandini 2015)

In this category, we can also have Hub which is a particular physical environment and meeting point where people who often do not know each other previously, experiment moments of serendipity. Among 'hubs' a 'business' component seems more frequent than a 'making' component (Stercken 2015). We can also have the Techshop, which are vast private spaces, based on a principle of openness, with a very low access price. They are hybrid places between collaborative workspaces and Fablabs (Bouvier-Patron 2015).

Finally, I am aware that the boundaries between these different spaces are not sealed, because they have many similarities in practices, ideologies, organization...which make their separation unclear. It is clear that within the maker movement there are many advantages for society, citizens and humanity. These advantages are broadly reported in the media and scientific literature, giving the sensation that only the positive face of the movement exists. The next section is devoted to the dual consequences (positive and negative) of the maker movement in society.

\section{BENEFITS AND THE HIDDEN FACE OF THE MAKER MOVEMENT}

\section{Benefits}

The benefits related to engagement with the maker movement are threefold: social, political and economic.

\section{Social benefits}

\section{- Education}

According to many authors it is very important to add a collaborative creative space at all levels of the traditional model of school (nursery, primary, secondary, university, professional).

The maker movement improves personal skills, and enhances the interest in Science, Technology, Engineering, and Mathematics (STEM). For Barniskis (2014), it is more than STEM, it is STEAM (just add Arts), because Art can become more participatory and collaborative for students using makerspace tools and ideas.

\footnotetext{
Makerspace offers fresh opportunities to join forces on projects and education with people who may never have considered themselves artists, or with tools artists rarely use. In either case, makerspaces are seeking creators of all stripes to teach classes, to join as members, or perhaps to partner with, in teaching students. (Barniskis 2014)
}

The presence of collaborative creative spaces in school can be helpful for specialized education or education of students with intellectual disabilities: "makerspaces offer a 
way for struggling students to gain confidence and experience a sense of success and belonging" (Brady et al. 2014).

Combining libraries and makerspaces is also very important, since the presence of $3 \mathrm{D}$ printers in the library reanimates the interest for these kinds of places (Finley 2016).

Creative librarians are translating public libraries' mission of ensuring access to information into more tools and hands-on classes, as well as books and videos. Some library makerspaces are digital media labs, with little or no prototyping equipment. Others are geared to a particular art form that is in high demand. One library is adding a fibre arts makerspace that developed from its popular knitting classes; it includes looms, a spinning wheel, ballwinders, and swifts for yarn enthusiasts to share. Users of this space largely use computers in this space to share patterns and blogs about their projects, though pattern-creation software would be a welcome addition. (Barniskis 2014)

- Socialization

The maker movement allows the exchange of ideas and the display of creation; it provides informal spaces of work where users can meet other people or groups (Brady et al. 2014; Bilandzic and Foth 2013). Aligned with Keulartz and van den Belt's (2016) thinking, the maker movement is responsive to the community, it is in search of a fruitful synergy between technology development and community building. There is no discrimination between experts and non-experts, "the relationships between amateurs and professionals are thus not only located 'in' disciplinary fields or specific places (the usual sites that locate the amateur/professional boundary), they are also made possible 'through' objects” (Meyer 2013).

\section{Economic Benefits}

Chris Anderson (2010), a great promoter of the maker movement, sees it as the next industrial revolution, where at a low cost anyone can be an inventor and entrepreneur. According to him, this situation is facilitated by : the crowdsourcing of design, the release of design under a share-friendly Creative Commons license, the collective potential of a million garage tinkerers; the fact that "the Internet democratized publishing, broadcasting, and communications, and the consequence was a massive increase in the range of both participation and participants in everything digital". Another reason but not the least is the change driven by two forces:

\footnotetext{
First, the explosion in cheap and powerful prototyping tools, which have become easier to use by non-engineers. And second, the economic crisis has triggered an extraordinary shift in the business practices of (mostly) Chinese factories, which have become increasingly flexible, Web-centric, and open to custom work (where the volumes are lower but the margins higher). (Anderson 2010).
}

As digital technology becomes cheaper and more ubiquitous, they are offering possibilities to quickly switch from concept to prototype, then to the unit and / or serial development, without even using companies and with or without the prospect of a commercial project (Bouvier-Patron 2015). 
That said, the tools and equipment do offer astounding opportunities to do new things, hack existing objects, and be creative, especially the Computer-Aided Design equipment. The additive production equipment, namely, 3D printers, allow users to quickly and cheaply build everything from sculpture to gadgets, using simple software. (Barniskis 2014)

\section{Political Benefits}

According to Kera (2014), the maker movement redefines the sense of power dynamics. We are moving from the traditional model based on the separation of the executive from the normative, towards a more holistic approach based on the attempts of rules constantly adapted according to the changes of the actors. Democratization of science and empowerment are key concepts in this change, they allow people to aspire to a real participative democracy with an effective public engagement, in order to build their future themselves. That is why, on the one hand, space related to maker movement appears like a place of counterculture, offering a self-managed and anti-capitalist vision of technical and scientific knowledge. On another hand, they are places of libertarian resistance to surveillance and state control (Goldenberg 2014; Bouvier-Patron 2015). But for authors, these assumptions are more complex than they were put forward. Lindtner (2014) says that: "The maker culture is better understood as a parasitic culture rather than a counterculture, altering the system from within, contributing to our understanding of the relationship between technology use, production, society, activism and the state." Hunsinger and Schrock (2016) add the possible collaboration of hacker culture with institutions: "Yet, a splintering of hacker cultures has disrupted easy assumptions about their countercultural or resistant nature. Quite contrary to anti-authoritarian stereotypes, hacker collectives increasingly work with institutions and corporations to bring about social change".

\section{- Empowerment}

The maker movement allows people to be creative and autonomous in solving any relevant local problem, just their minds, hands, eyes and brain are necessary. Trusting institutions, gleaming labs, peer control and judgement are not required. Accordingly, Barkinis (2014) says: "the hacker attitude encourages people to tinker, to fail, to experiment, to make things better. Many of the projects filling the metal shelves ubiquitous to makerspaces are old electronics, gadgets, or tools that makers are changing to do things they were never intended to do before"

- Democratization of science.

This benefit comes from the citizen science movement, and aims at the demystification and democratization of science by opening it up to public participation, giving citizens access to data (Landrain et al. 2013; Meyer 2012; Keulartz and van den Belt 2016). Besides this aspect, the maker movement facilitates access to a computer, Internet, hardware and software for people who cannot afford them (Bilandzic and Foth 2013).

In the academic literature, the majority of scientific papers promote the maker movement, by putting forward their advantages for society, citizens, culture...I am aware that these benefits are impactful and can contribute to the development of low-income countries. But this pattern of literature hides the worst side of the 
movement, which should be taken in account, because it is critical if we really want to take advantage of the maker movement.

\section{The hidden face of the maker movement}

\section{Sustainability of collaborative and innovative spaces}

Regarding the advertisement around the maker movement, it seems too easy to say that spaces are open to everybody; tools, machines, hardware, software and the Internet are available for all. But since these spaces consume energy, time, human resources... what makes them sustainable? For successful and sustainable spaces, some conditions are critical, namely: accessibility, community, management, funding, political support.

- Accessibility - collaborative and innovative spaces should be created in environments outside institutional or academic control and where more people can access.

- Community - collaborative spaces are bound in the community that creates them, and the wide variety of ages and skill levels found in that community. "while the tools and equipment are important, a participatory culture of community building is vital to a strong makerspace; tools and equipment are less important than the pool of knowledge held within the community" (Barniskis 2014).

- Management - these spaces should be managed as "a permeable organization that is open to new people, ideas and other organizations. This permeability brings a continuous inward flow of ideas and inspiration that are brought into the organization and into communication with all forms of management" (Bell et al. 2014).

- Funding - The initial setup of collaborative spaces can be expensive, regarding technology, equipment, and the start-up costs. Then we will have costs for maintenance, services, and others. The space can be funded as a cooperative, meaning that members should contribute. Usage fees, donations, government support can also be helpful. Other funding options are:

Events such as makerspace fairs, fundraising campaigns or creating maker clubs can all be sources of revenue to help sustain and/or expand on services and options associated with makerspace activities [...]Another aspect is to look at funding options, including grant funding as either a start-up or service investment and the opportunities that can be created to develop a sustainable model of revenue that helps offset the costs associated with these activities. Developing a makerspace can be much the same as starting a business and creating a business plan for growth. (Crumpton 2015)

- Political support is important to create a safe and confident environment where makers, citizens, and civil society organizations can express their creativity. It is also important that decision makers align their policy agenda with the maker movement: 
President Obama called for one thousand new makerspaces in high schools, and the Defense Advanced Research Projects Agency is teaming up with makers to facilitate these spaces, in order to promote science, technology, engineering, and math (STEM) learning, innovation, and technical skills in a new generation of workers. (Barniskis 2014)

\title{
Capitalism Behind Alternative Economies
}

The interesting faces of the maker movement is the constant evocation of: community, sharing, accessibility and horizontal authority. These ideas seem aligned with Ostrom's principles on Commons (Williams and Hall 2015). Meaning that, it is not, in principle, business-oriented (Gandini 2015). But if we consider equipment used in the maker movement, it appears that from the basic components like micro-censors, Arduino, Raspberry Pi... to 3D printers, CNC, laser cutters and so on, the majority of these equipments come from Chinese factories as Anderson (2010) has already mentioned. Many of these products are recommended on the Web or in specialized journals like Make (http://makezine.com/); this encouragement of consumption is not too far from the Fordist perspective of capitalism. Since many of these products are selling online, using platforms like Amazon (www.amazon.com), we can just make the parallel with all critics of the GAFAM (Google-Amazon-Facebook-Microsoft). Add to this, according to the idea of free sharing, that all the makers of the world are contributing online and generate free contents; but these free contents can be used by someone to gain profits. Another aspect is that, in many makerspaces and hackerspaces, when a successful prototype is built, the plans are sent to China for multiplication of the object. All these procedures are just the capitalist process hidden behind alternative economies driven by the Internet such as: sharing economy, collaborative economy, knowledge economy, circular economy...l don't want to say that these economies are not alternative to capitalism, but I want to stress the fact that they are parasitized by capitalism and the quest for individual profits.

The quest for profit is also very present in biology and DIYBio; Keulartz and van den Belt (2016) talk of biocapitalism to qualify the ambivalent relationship between DIYbio and capitalism. This ambivalence involves economics and ethics:

\begin{abstract}
despite its rebellion against the ruling principles of the academicindustrial research complex, DIY-Bio is not entirely free to steer its own course vis-à-vis Big-Bio. For one thing, there is a relationship of dependency concerning cheap, second-hand products for amateurs [...] DIY-Bio's relationship with Big-Bio is ambivalent in yet another way. On the one hand, biohackers act as rebels who challenge the status quo by advocating free access and sharing; on the other hand, they may also act as profiteers who resist external interference from public regulations, corporate interests, or academic institutions, in order to accumulate economic profit as well as personal prestige. (Keulartz and van den Belt 2016)
\end{abstract}

\section{Inequalities \& Exclusion}

The public discourse on the maker movement is strongly oriented towards concepts of openness and egalitarianism. However, what happens inside collaborative and 
creative spaces is exclusion and inequalities related to: localization, identity (gender, race), meritocracy and social needs.

- Localization

The majority of spaces related to the maker movement are located in the Western world, especially in the US and European cities. Thus, the discourse on the benefits of this movement reflects their reality which does not fit in with the realities of Africa, Asia, etc.

- Identity

Schor et al. (2016) on gender, point to the fact that collaborative spaces reflect a masculine geek identity and this is a source of strong gender differentiation in the pattern of activities that people engage in. They also found that "those with conventional class and race privilege were able to translate that privilege even within the informal institutional environment of making". They qualify these spaces as "space of whiteness", particularly in the US context. Nonetheless, gender domination and racism are contrary to openness ethos.

- Meritocracy

Describing some maker and hackerspaces in the US, Schor et al. (2016) remark that people in these spaces are ranged according to skills: " people range in ability from hobbyists and tinkerers to professional engineers and craftspeople, with experienced members acting as instructors and advisors for novice makers". They also acknowledged that: "new members had to establish themselves if they were to collaborate with high-status members". At this point, the ideal of equality is seriously engaged.

\section{- Social Needs}

Many projects in makerspace do not reflect social needs. Schor et al. (2016) deplore that "many of the projects are technologically sophisticated, ranging from giant robots to complex circuitry". How can a peasant be interested in sophisticated technology, for example? Some people will be marginalized even if they are there for "decoration".

I think the maker movement is a great chance for Africa to face poverty and underdevelopment. To solve local problems, all these benefits can be used by politicians, civil society organizations, women, youth, etc. But even if advantages and disadvantages presented here are also relevant in African context, we should not forget that they are connected to Western realities. We don't really know how powerful the movement is for Africa, because we are just reproducing the western model of collaborative spaces. My thought is that, the cultural-sensitive implementation of the maker movement in Africa is the best way for the continent.

\section{AFRICANIZATION OF THE MAKER MOVEMENT}

Pablo and Juárez (2013) advise us to be careful in fully replicating collaborative spaces in our context, since the implementation of fablab in Latin America encounters adverse circumstances such as:

Economic Factor. The acquisition of tools and digital fabrication equipment in Latin America can be between 3 to 8 times more expensive than in Europe or the U.S. (import expenses, transportation, customs, cost of living,etc.). Management and 


\begin{abstract}
Maintenance. A Fabrication Laboratory is a space with machines such as an ink plotter, so that maintenance and permanent staff are required, to give a short-term solution to these needs, and this requires expertise and training. [...] applications and implications for digital fabrication since 2008 are on average 6.5 times more expensive in Latin America and even up to 40 times in some African countries. Administrative Factor. Bureaucracy is still another problem for creating and implementing a Digital Fabrication Laboratory, especially those promoted by public entities. Even with funding, the implementation of Fab Lab Lima took nine months, which is three times more than in the U.S. or Europe. An even more extreme case is Fab Lab Addis Ababa in Ethiopia, which under similar conditions to that of Lima, took 24 months to complete its installation. Educational Factor. The implementation in Europe and the U.S. occurs in spaces that encourage design issues on the instrumentalization of a process. In Latin America the implementation of technologies still exists as an extension or continuation of the practice of drawing and, not being integrated into the design, aims at education for technological consumption, but not development or discovery. As a result, most professionals, companies, or government organizations centralize their activities only in production/trade and very rarely in innovation.(Pablo and Juárez 2013)
\end{abstract}

So, in order to benefit from all advantages driven by the maker movement, its implementation in the African context should first consider hidden points mentioned above and, secondly, take into account our cultural specificities. This is what I am calling the Africanization of the maker movement, which is aligned with the cultural model of technological appropriation advocated by Bar, Weber and Pisani (2016). To me, the right way to contextualize the maker movement in Africa is twofold: align its missions with the quest for cognitive justice and really consider the maker movement and related spaces as commons.

\title{
The Quest for Cognitive Justice in Africa
}

In her work on "cognitive justice" in Africa, the anthropologist Florence Piron has shown that cognitive justice is a powerful weapon, which can ensure a fair and sustainable local development. As proposed by Shiv Visvanathan (2009), cognitive justice can be defined as an epistemological, ethical and political ideal aimed at the emergence of socially relevant knowledge: "un idéal épistémologique, éthique et politique visant l'éclosion de savoirs socialement pertinents partout sur la planète et non pas seulement dans les pays du Nord, au sein d'une science pratiquant un universalisme inclusif, ouvert à tous les savoirs" (Piron, Madiba, and Regulus 2016). The quest for cognitive justice is devoted to two missions: value the knowledge of the global south, whether scientific or not; and align science/scientists with the concerns of local populations and their vision of sustainable local development. The achievement of these missions in Africa is possible by fighting inequities (Piron 2016), through:

- The refusal of marginalization and disregard to local knowledge, relegated to being mere beliefs, superstition or "culture";

- The promotion of local languages instead of colonial languages, because this unjust detour does not allow us to express fully the basis of our 
original thought; the abolishment of all barriers to knowledge and the Internet;

- The avoiding of sealed boundaries between science and society, by promoting citizen sciences and allowing experts and non-experts to work together in order to solve the problems of their city;

- The democratization of science with the help of policymakers who should promote open science, citizen sciences and build sustainable infrastructure which can support the sharing and full expression of knowledge.

\section{The maker movement as a Commons}

In the first part of my paper, the presentation of the maker movement showed that it is very sensitive to shared resources and collectivity, which are core values of the concept of Commons as established by Ostrom (1990; 2009). For the maker movement to fully succeed in Africa, it should be aligned with the idea of Commons. According to many different authors (Azam 2013; Coriat 2015b; Coriat 2015a; Hess 2008; Ostrom 1990; Coriat 2016; Bollier et Helfrich 2014; Bollier, Petitjean, et Le Crosnier 2013), a commons exists only if these three values are present: resources, communities and management by co-property.

- A resource which can be tangible or intangible. Tangible resources are palpable or material resources, whereas we cannot touch intangible resources(Coriat 2015b). The bulk of these intangible resources exists in the form of information. This value points to the fact that the creative space is not only composed of physical resources (tools, machines, 3D printer, CNC...), it can also be an idea, a song, a story... In a makerspace, this point is very important because, depending on the nature of the resource, people will be interested in socializing with the place.

- Community using, protecting and taking care of available resources. A community is not just human actors; non-humans are also comprised. That is why Thomé (2014) says a community is built by three types of actors: public-institutional actors (UN, EU, AU, States...), private institutional actors (companies, multinationals...) and autonomous actors (populations, civil society organizations). All these actors are present in hacker and makerspaces as users, managers and funders. The challenge with all these actors is the dynamics of power. At this point we have to understand if what is happening in the place is the effect of funders or managers instead of people or citizens.

- Management and the bundle of rights. The idea of a community around a resource implies a set of rules that define its use. Rules set by all members of the community and not an individual.

Common property is a formal or informal legal regime that allocates various forms of rights to a group...there can be different types of rights involved in commons property: access, extraction, management, exclusion, and alienation rights. The types of rights are determined not only by the regime but by the nature of the resource. (Hess 2008) 
According to Coriat (2015), there are two sets of rules. Those at operational level deal with access and exploitation, regarding users and authorized persons. Those at the management level are used to regulate the use of the resource; and to exclude or accept people. This point is crucial for the maker movement in Africa, because if well used it will translate the concept of openness. But wrongly used, it will conduct to exclusion and the reproduction of hierarchy.

\section{CONCLUSION}

I conclude this paper with a call to African stakeholders engaged in the maker movement (promoters, politicians, funders, citizens...). It is to our benefit to adopt the maker movement in order to face poverty with technology and democratization of science. But we should not do it blindly, by reproducing the western model for our continent. The hidden face of the movement I presented above is not to discourage its adoption, but to better surround the phenomenon and avoid some mistakes. This critical posture will ensure to keep on the right track the ideals of the maker movement in the African movement. Definitely, the Africanization of the maker movement through the quest for cognitive justice and the philosophy of the Commons, seems to be the best way to build a culturally sensitive maker movement.

Artigo recebido em 31/01/2017 e aprovado em 11/05/2017.

\section{BIBLIOGRAPHY}

Anderson, Chris. 2010. "Atoms Are The New Bits." Wired 18 (2): 58-58.

Anderson, Chris, and Michel Le Séac'h. 2012. Makers: la nouvelle révolution industrielle. Paris: Pearson.

AZAM, Genéviève. 2013. "Les Communs, Quelles Définitions, Quels Enjeux ?" https://www.canal-

u.tv/video/universite_toulouse_ii_le_mirail/les_communs_quelles_definitions_quels_ enjeux_genevieve_azam.13502.

Bar, François, Matthew S. Weber, and Francis Pisani. 2016. "Mobile Technology Appropriation in a Distant Mirror: Baroquization, Creolization, and Cannibalism." New Media \& Society 18 (4): 617-36. doi:10.1177/1461444816629474.

Barniskis, Shannon Crawford. 2014. "Makerspaces and Teaching Artists." Teaching Artist Journal 12 (1): 6-14. doi:10.1080/15411796.2014.844621.

Bell, Frances, Gordon Fletcher, Anita Greenhill, Marie Griffiths, and Rachel McLean. 2014. "Making MadLab: A Creative Space for Innovation and Creating Prototypes." Technological Forecasting and Social Change 84 (May): 43-53. doi:10.1016/j.techfore.2013.09.004.

Bilandzic, Mark, and Marcus Foth. 2013. "Libraries as Coworking Spaces: Understanding User Motivations and Perceived Barriers to Social Learning." Edited by Mu-Yen Chen. Library Hi Tech 31 (2): 254-73. doi:10.1108/07378831311329040.

Bollier, David, and Silke Helfrich. 2014. The Wealth of the Commons: A World Beyond Market and State. Levellers Press. 
Bollier, David, Olivier Petitjean, and Hervé Le Crosnier. 2013. La renaissance des communs pour une société de coopération et de partage. Paris: C. L. Mayer.

Bosqué, Camille. 2015a. "Des Fablabs Dans Les Marges: Détournements et Appropriations.” Journal Des Anthropologues.

- 2015b. "Enquête au cœur des FabLabs, hackerspaces, makerspaces: Le dessin comme outil d'observation." Techniques \& culture, no. 64 (December): 168-85. doi:10.4000/tc.7579.

Bouvier-Patron, Paul. 2015. "FabLab et extension de la forme réseau: vers une nouvelle dynamique industrielle ?" Innovations 47 (2): 165. doi:10.3917/inno.047.0165.

Bowen, Lauren Marshall. 2017. "The Limits of Hacking Composition Pedagogy." Computers and Composition 43 (March): 1-14. doi:10.1016/j.compcom.2016.11.001.

Brady, Tara, Camille Salas, Ayah Nuriddin, Walter Rodgers, and Mega Subramaniam. 2014. "MakeAbility: Creating Accessible Makerspace Events in a Public Library." Public Library Quarterly 33 (4): 330-47. doi:10.1080/01616846.2014.970425.

Buclet, Nicolas. 2015. "Le Territoire Créateur de Ressources: Une Illustration Autour Du Cas Usinette.” Métropolis 1 (99): 45-57.

Capdevila, Ignasi. 2015. "Les Différentes Approches Entrepreneuriales Dans Les Espaces Ouverts D'innovation.” Innovations 3 (48): 85-105. doi:10.3917/inno.048.0087.

Coriat, Benjamin. 2015a. Le Retour Des Communs: La Crise de L’idéologie Propriétaire. Les liens qui libèrent.

- 2015b. Les Biens Communs, Un Enjeu Politique. https://www.youtube.com/watch?v=RKLhkjgGWNg.

2016. "Ne Lisons Pas Les Communs Avec Les Clés Du Passé. Entretien Avec Benjamin Coriat - CONTRETEMPS." Accessed November 24. http://www.contretemps.eu/ne-lisons-pas-les-communs-avec-les-cles-du-passeentretien-avec-benjamin-coriat/.

Crumpton, Michael A. 2015. "Fines, Fees and Funding: Makerspaces Standing Apart." Bottom Line 28 (3): 90-94. doi:10.1108/BL-04-2015-0004.

Eychenne, Fabien. 2012. Fab lab l'avant-garde de la nouvelle révolution industrielle. Limoges]; [Paris: FYP éd. ; FING.

Finley, Thomas K. 2016. "The Impact of 3D Printing Services on Library Stakeholders: A Case Study." Public Services Quarterly 12 (2): 152-63. doi:10.1080/15228959.2016.1160808.

Gandini, Alessandro. 2015. "The Rise of Coworking Spaces: A Literature Review*." Ephemera 15 (1): 193-205.

Goldenberg, Anne. 2014. "Les hackerspaces comme politisation d'espaces de production technique. Une perspective critique et féministe." Mouvements 79 (3): 57. doi:10.3917/mouv.079.0057.

Hess, Charlotte. 2008. "Mapping the New Commons." SSRN Electronic Journal. doi:10.2139/ssrn.1356835.

Himanen, Pekka. 2001. L'éthique hacker et l'esprit de l'ère de l'information. Paris: Exils. 
Hunsinger, Jeremy, and Andrew Schrock. 2016. "The Democratization of Hacking and Making.” New Media \& Society 18 (4): 535-38. doi:10.1177/1461444816629466.

Kera, Denisa. 2014. "Innovation Regimes Based on Collaborative and Global Tinkering: Synthetic Biology and Nanotechnology in the Hackerspaces." Technology in Society 37 (May): 28-37. doi:10.1016/j.techsoc.2013.07.004.

Keulartz, Jozef, and Henk van den Belt. 2016. "DIY-Bio - Economic, Epistemological and Ethical Implications and Ambivalences." Life Sciences, Society and Policy 12 (1). doi:10.1186/s40504-016-0039-1.

Kojo, Inka, and Suvi Nenonen. 2014. "Evolution of Co-Working Places: Drivers and Possibilities." Intelligent Buildings International, December, 1-12. doi:10.1080/17508975.2014.987640.

Lallement, Michel. 2015. L'âge du faire: hacking, travail, anarchie. Paris: Editions du Seuil.

Landrain, Thomas, Morgan Meyer, Ariel Martin Perez, and Remi Sussan. 2013. "Do-ltYourself Biology: Challenges and Promises for an Open Science and Technology Movement." Systems and Synthetic Biology 7 (3): 115-26. doi:10.1007/s11693-013-91164.

Lindtner, S. 2014. "Hackerspaces and the Internet of Things in China: How Makers Are Reinventing Industrial Production, Innovation, and the Self." China Information 28 (2): 145-67. doi:10.1177/0920203X14529881.

Meyer, Morgan. 2012. "Bricoler, domestiquer et contourner la science : l'essor de la biologie de garage.” Réseaux 173-174 (3): 303. doi:10.3917/res.173.0303.

—. 2013. "Domesticating and Democratizing Science: A Geography of Do-ltYourself Biology." Journal of Material Culture 18 (2): 117-34. doi:10.1177/1359183513483912.

Nedjar-Guerre, Akila, and Anne Gagnebien. 2015. "Les fablabs, étude de cas: Le faclab de Cergy-Pontoise à Gennevilliers est-il un lieu d'expérimentation sociale en faveur des jeunes ?" Agora débats/jeunesses 69 (1): 101. doi:10.3917/agora.069.0101.

Ostrom, Elinor. 1990. Governing the Commons: The Evolution of Institutions for Collective Action. The Political Economy of Institutions and Decisions. Cambridge; New York: Cambridge University Press.

2009. "Beyond Markets and States: Polycentric Governance of Complex Economic." In . https://www.nobelprize.org/nobel_prizes/economicsciences/laureates/2009/ostrom_lecture.pdf.

Pablo, Herrera, and Benito Juárez. 2013. "Fabrication Laboratories: Problems and Possibilities of Implementation in Latin America.," July. http://repositorioacademico.upc.edu.pe/upc/handle/10757/605215.

Piron, Florence, Sophie Madiba, and Samuel Regulus. 2016. "Justice Cognitive, Libre Accès et Savoirs Locaux | Production Simple Book." https://scienceetbiencommun.pressbooks.pub/justicecognitive1/.

Schor, Juliet B., Connor Fitzmaurice, Lindsey B. Carfagna, Will Attwood-Charles, and Emilie Dubois Poteat. 2016. "Paradoxes of Openness and Distinction in the Sharing Economy." Poetics 54 (February): 66-81. doi:10.1016/j.poetic.2015.11.001. 
Stercken, A. M. 2015. "Cultivating Serendipity and Efficacy Beliefs: The Impact of (Caireen) Innovation Spaces on Human Development." Master thesis. http://dspace.library.uu.nl/handle/1874/305357.

Thomé, Pierre. 2014. “files_2014_11_bien-Commun-Ou-Biens-communs_2014.pdf." http://base.socioeco.org/docs/_files_2014_11_bien-commun-ou-biens-

communs_2014.pdf.

Visvanathan, Shiv. 2009. "The Search for Cognitive Justice." http://www.indiaseminar.com/2009/597/597_shiv_visvanathan.htm.

Williams, Michael R., and Joshua C. Hall. 2015. "Hackerspaces: A Case Study in the Creation and Management of a Common Pool Resource." Journal of Institutional Economics 11 (4): 769-81. doi:10.1017/S1744137415000016. 